\title{
Microbial analysis of leafy vegetables in iceless
}

\section{cooling facility}

\author{
Fuseini Jacob Yakubu ${ }^{1}$, James Natia Adam², Al-hassan Issahaku ${ }^{3}$ \\ ${ }^{1}$ Department of Science, Bagabaga College of Education, P.O. Box ER 35, Tamale, Ghana \\ ${ }^{2}$ Zonzongili Development Associates, P.O. Box ER 262, Tamale, Ghana \\ ${ }^{3}$ Independent M\&E Consultant, P.O. Box TL 1268, Tamale, Ghana
}

\begin{abstract}
Against the background that leafy vegetables stored under ambient conditions are influenced by environmental factors which may cause significant quality loss in terms of freshness, colour, texture and composition, the iceless cooler was used to evaluate microbial load of leafy vegetables. The samples were evaluated for bacterial (coliforms and mesophiles) and fungal (mold and yeast) loads. Results of the microbial test showed that Corchorus olitorius had highest mean microbial load with plate count of $6.7 \times 10^{4} \mathrm{CFU} / \mathrm{g}$ and Hibiscus sabdariffa had the least mean microbial load with plate count of $4.8 \times 10^{4} \mathrm{CFU} / \mathrm{g}$ after five days of storage. Corchorus olitorius show a significant increase of Escherichia coli, Staphylococcus aureus and Streptococci species after five days of storage. The ANOVA results showed that vegetables stored under ambient conditions were significantly different $(p<0.01)$ from those stored in the iceless cooler. The results also indicate that Amaranthus dubius recorded the highest mean weight of $1.94 \mathrm{~kg}$ and maintained its freshness and colour for up to three days compared with Corchorus olitorius with the least weight of $1.84 \mathrm{~kg}$.
\end{abstract}

Keywords-Amaranthus dubius, Corchorus olitorius, Deterioration, Hibiscus sabdariffa and Storage.

\section{INTRODUCTION}

Leafy vegetables such as Amaranthus dubius, Corchorus olitorius and Hibiscus sabdariffa are important traditional vegetables cultivated in the three Northern Regions of Ghana because of their health benefits (Amaglo \& Nyarko, 2012). These vegetables contain high sources of proteins, carbohydrates, vitamins and minerals which are essential for a healthy human life (Buyukunal et al, 2015). However, leafy vegetables farmers in Ghana do not posses adequate hygienic production information and good agricultural practices (e.g., storage of vegetables) and thus, posing high potential public health risk (Adam et al., 2016). Knowledge and good skills of leafy vegetable storage is very important in order to help maintain the nutrient composition and texture.

According to O'Connor-Shaw et al. (1996) microbial spoilage is a limiting factor for shelf life of leafy vegetables and fruit specie stored under controlled atmosphere conditions. Shelf life, including microbial spoilage results in 30-50\% shrinkage of fresh-cut fruits and leafy vegetables (Warren, 2005). Contamination sources of fresh-cut fruits and vegetables include raw materials and contact with processing equipment. The microorganisms that exist on the surfaces of raw, whole produce appear to be the major source of microbial contamination and consequent spoilage of fresh-cut fruits and vegetables. Boyette et al. (1993) indicate that the microbial decay of fresh-cut lettuce is largely due to the growth of microorganisms originating from pre-harvest environments. Delaquis et al. (1999) indicate that the types of microorganisms found on shredded lettuce were highly associated with the microorganisms detected on lettuce before shedding.

Microbial spoilage including off-flavor formation, slimy surface, wetness and soft rot, discoloration, and visual microbial growth/colonies has been used as a main or exclusive objective criterion to determine shelf life of fresh-cut products (O'Connor-Shaw et al., 1994; Sapers et al, 2001,). Jacxsens et al. (2003) reveal that green, yellow and red bell pepper was unacceptable by day 6 of storage under atmospheric condition of $7^{\circ} \mathrm{C}$ due to acidic flavor, water loss and texture change. Also, Allende et al. (2004) indicate that processed Lollo Rosso lettuce had a shelf life shorter than 7 days at $5^{\circ} \mathrm{C}$ due to high microbial counts and off-odor formation under MAP. It therefore suggests that leafy vegetables deteriorate quickly due to the active process of senescence and biochemical processes which change the original composition of the crop.

The lack of appropriate vegetable storage techniques often times result in post-harvest loss (Adam et al., 2016). This is because storage of harvested products under controlled conditions is known to retard the growth of postharvest spoilage and pathogenic microorganism (Nguyen \& Cardin, 1994). The reasons for the lack of adoption of modern storage technologies by vegetable farmers include huge cost of storage facilities coupled with unstable electricity power (Adam et al., 2016; Gogo et al., 2016).

As an alternative to the modern technologies for storing fruits and leafy vegetables, Nicol et al. (1997) suggested the use of iceless coolers by farmers and traders who 
cannot afford to acquire improved storage technologies and equipment. The iceless cooler can be made up of a wooden frame with dimensions of $0.7 \mathrm{~m} \times 0.7 \mathrm{~m} \times 1.2 \mathrm{~m}$. The sides of the frame are covered with jute sacks. The top water trough is filled with water regularly to soak the jute sacks at the sides of the coolers. The iceless cooler also has a water trough at the base which collects excess water. The coolers are kept in an open shaded area where there is good flow of air current. Energy from the air current is used in evaporating the water at the sides of the cooler and also to preserve the vegetables.

The arguments for the iceless cooler is that the equipment is less expensive and built on simple home-made technology which can keep fruits and vegetables for longer periods of time. The iceless cooling facility works on simple principles of evaporative cooling to conserve the quality and shelf life of leafy vegetables. However, there is very limited information regarding how changes in atmospheric composition affect spoilage microflora profile during iceless cooling storage of leafy vegetables. The main objective of this study was to assess the effects of iceless cooling facility on microbial development, quality and shelf life of traditional leafy vegetables.

\section{LITERATURE REVIEW}

The common types of leafy vegetables cultivated in Northern Region of Ghana include Amaranthus dubius, Hibiscus sabdariffa, Corchorus olitorius, bitter leaf, baobab leaves, lettuce, cabbage and asparagus. Amaranthus dubius (Aleefu) known as Amaranth is a dark green cosmopolitan genus of annual or short-lived perennial leafy vegetable in Africa, India, Bangladesh, Sri Lanka and the Caribbean. The vegetable forms an important source of plant protein (Babalola et al., 2010), which is very useful for treating fever. The vegetable also contains vitamins (A and C) and minerals (potassium, iron, magnesium and calcium) in the diet of people (Smith \& Eyzaguirre, 2007; Tweneboah, 2000). Amaranth leaves in general are recommended as a good food with medicinal properties for young children, lactating mothers and for patients with fever, haemorrhage, anaemia, stomach ache (Schippers, 2002), constipation or kidney complaints. It is also an excellent nutritional food for AIDs patients especially when Amaranth grain porridge (1 cup) is combined with moringa leaf powder (1 table spoon) (Babalola et al., 2010).

Corchorus olitorius (ayoyo) is a native plant of tropical Africa and Asia, and has since spread to Australia, South America and some parts of Europe. It is popularly used in soup preparation and folk medicine for the treatment of fever, chronic cystitis, cold and tumours. Scientists have indicated that drinking vegetable juice freshly made with Corchorus olitorius in an empty stomach can prevent and cure Ebola Virus Disease. It is also reported that www.ijeab.com
Corchorus olitorius has the power to clear or open the natural ducts of the fluids and secretions of the body, as well as encourages lactation, purgative and tonic solving aches and pains, dysentery, enteritis, fever and tumors. Corchorus olitorius leaves are also rich sources of potassium, iron, copper, manganese, zinc and high energy values essential in human and animal nutrition.

Hibiscus sabdariffa (Roselle) is an important annual crop grown successfully in tropical and sub-tropical climates. The plant is cultivated for its stem, fibre, edible calyces, leaves and seeds which are used in making various foods. The commercially important part of the plant is the fleshy calyx (sepals) surrounding the fruit (capsules). It is used for making wine, juice, jam, jelly, syrup, gelatin, pudding, cakes, ice cream and flavours and also dried and brewed into tea, among other things (Solomon, 2013). Hibiscus is used for treating loss of appetite, colds, heart and nerve diseases, upper respiratory tract pain and swelling (inflammation), fluid retention, stomach irritation, and disorders of circulation. It is also good for dissolving phlegm. According to Jonadet et al. (1990) Hibiscus can be used as a laxative and diuretic to increase urine output. Calyces of the red and dark red coloured type are extracted and sweetened to produce a refreshing drink while calyces and leaves of the green type are used for making vegetable stew (Babalola, 2001).

\section{MATERIALS AND METHOD}

\subsection{Research design}

The experimental design was a randomized complete block design. Nine samples of Corchorus olitorius, Hibiscus sabdariffa and Amaranthus dubius were bought from the Tamale central market to serve as control. Samples were also taken from the vegetables cultivated purposely for this research work. Harvested vegetables were weighed and kept inside the iceless cooler facility. Temperature readings and relative humidity inside and surroundings of the coolers were taken thrice a day at 9:00am, 12noon and 3:00pm. Daily records on colour change, freshness and weight loss of the vegetables taken.

\subsection{Preparation of smears}

A drop of physiological saline was placed on a clean grease free glass slide. A sterile inoculating loop was used to transfer a colony to the slide and emulsified to make a smear. The slides were left to air-dry before heat fixing, using the flame of a Benson burner to properly adhere the smear on the slides as well as preserve microorganisms and prevent smears from being washed from the slides. Smears were allowed to cool before staining.

\subsection{Gram staining of cultures}

Gram staining was done to help identify the gram status and morphology of organisms. The fixed smear was 
covered with crystal violet stain for 60 seconds and rapidly washed off with tap water. The smear was covered again with Lugol's iodine for 60 seconds and washed off with tap water. Acetone- alcohol solution was used to decolorise the stain for only 10 seconds and immediately washed off with tap water. The smear was covered again with neutral red stain (safranin) for 1 minute and washed off with tap water. The slides were placed in a draining rack for the smear to air dry. The smears were examined microscopically with oil immersion objective to report the gram status and morphology of bacteria.

\subsection{Microbial load tests}

Ten (10) grams of chopped vegetable each was weighed into each sampling bottle containing 90 millilitres $(90 \mathrm{ml})$ of peptone water, making a dilution of $10^{-1}$. This was then agitated vigorously for two minutes to obtain homogeneity. One millilitre $(1 \mathrm{ml})$ of the sample inoculum was pipetted from the $10^{-1}$ dilution into a separate tube containing $9 \mathrm{ml}$ of peptone water to make a dilution of $10^{-}$ 2. The liquids were carefully mixed by aspirating 10 times with a sterile pipette and again $1.0 \mathrm{ml}$ transferred into another dilution tube containing $9 \mathrm{ml}$ of dilution peptone water and mixed to give $10^{-3}$. These dilutions were then ready for inoculation.

\subsection{Sample analysis}

Sterile plates count agars were labeled $10^{-1}, 10^{-2}$ and $10^{-3}$ and $0.1 \mathrm{ml}(100 \mu \mathrm{l})$ of the various dilutions inoculated. The inoculum was promptly spread on the surface of the plates using sterile glass spreader (Drigalsky spatulas). The plates were allowed to dry for 15 minutes before incubating in an inverted position at $35^{\circ} \mathrm{C}-37^{\circ} \mathrm{C}$ for 48 hours. Colonies were then counted and enumerated. All colonies in three plates corresponding to one dilution and showing between 30-300 colonies were counted. Averages of the replicates were calculated and multiplied by their dilution factor. This was then reported as the colony forming unit per gram (cfu/g). Overcrowded colonies were not counted and were reported as "Too Numerous to Count" (TNTC).

\subsection{Data analysis}

Using the Predictive Analytical Software version 21.0 and Student Edition of Statistix 9.0, the analysis was done to determine treatment effects on the quality parameters of the vegetables. The least significant difference at $5 \%$ and $1 \%$ level of significance were used to compare means of the vegetables kept under ambient conditions in the same vicinity with the cooling facilities for the same storage period of seven days. Microbial analysis on E. coli, Staphylococcus and Streptococcus was carried out at the Savannah Research Institute's laboratory in Tamale. Each day at $3 \mathrm{pm}$, the weight of the samples were taken using a top pan scale. The weight loss was measured in percentages over the storage period of seven days. Results of microbial population for the different conditions and their interaction effects were subjected to analysis of variance (ANOVA) and coefficient of variation.

\section{RESULTS}

\subsection{Quality parameters of leafy vegetables}

Table 1 presents the results on the quality parameters of leafy vegetables. Before storage of Amaranthus, there was 62,49 and 43 dilution on plate count giving an average colonies count of 51 which gave Cfu/g of $5.1 \times 10^{4}$. Amaranthus after storage recorded 73, 59, and 34 dilution on plate count, respectively giving an average of 55 and $\mathrm{Cfu} / \mathrm{g}$ of $5.5 \times 10^{4}$. For Corchorus, there was 73, 55 and 35 dilution on plate count giving an average colonies count of 54 and $\mathrm{Cfu} / \mathrm{g}$ of $5.4 \times 10^{4}$ before storage. After five days of storage of Corchorus, there were 82, 70 and 49 dilution on plate count respectively giving an average of 67 and $\mathrm{Cfu} / \mathrm{g}$ of $6.7 \times 10^{4}$. The results also indicate that Hibiscus had 57, 42 and 33 dilution on plate count giving an average colonies count of 44 and $\mathrm{Cfu} / \mathrm{g}$ of $4.4 \times 10^{4}$ before storage and 64,45 and 34 dilution on plate count, respectively giving an average of 48 and $\mathrm{Cfu} / \mathrm{g}$ of $4.8 \times 10^{4}$ after storage.

Table.1: Dilution on plate count average

\begin{tabular}{lcccccccccc}
\hline & \multicolumn{4}{c}{ Dilution on plate count } & \multicolumn{4}{c}{ After five days of storage } \\
Vegetable & $10^{-1}$ & $10^{-2}$ & $10^{-3}$ & $\mathrm{M}$ & $\mathrm{Cfu} / \mathrm{g}$ & $10^{-1}$ & $10^{-2}$ & $10^{-3}$ & $\mathrm{M}$ & $\mathrm{Cfu} / \mathrm{g}$ \\
\hline Amaranthus dubius & 62 & 49 & 43 & 51 & $5.1 \times 10^{4}$ & 73 & 59 & 34 & 55 & $5.5 \times 10^{4}$ \\
Corchorus olitorius & 73 & 55 & 35 & 54 & $5.4 \times 10^{4}$ & 82 & 70 & 49 & 67 & $6.7 \times 10^{4}$ \\
Hibiscus sabdariffa & 57 & 42 & 33 & 44 & $4.4 \times 10^{4}$ & 64 & 45 & 34 & 48 & $4.8 \times 10^{4}$ \\
\hline
\end{tabular}

Table 2 presents findings on average colonies count of Escherichia coli, Staphylococcus aureus and Streptococci species. The results of the study show that before storage of Amaranthus dubius, there was 143, 53 and 44 average colonies count of Escherichia coli, Staphylococcus aureus and Streptococci species, respectively compared with 52, 66 and 153 average colonies count after five days of storage. The findings suggest that there was a significant increase of Staphylococcus aureus and 
Streptococci species of Amaranthus dubius after storage in the iceless cooler.

The results on Corchorus olitorius show a significant increase of Escherichia coli, Staphylococcus aureus and Streptococci species after five days of storage. The average colonies count before storage was 96 Escherichia coli, 52 Staphylococcus aureus and 39 Streptococci species compared to 142 Escherichia coli, 60
Staphylococcus aureus and 149 Streptococci species after five days storage of Corchorus olitorius. The findings on Hibiscus sabdariffa showed a decrease of Escherichia coli and Staphylococcus aureus after five days of storage. The results also show an increase of Streptococci species from 142 colonies count before storage to 156 colonies count after storage.

Table.2: Average colonies count of E. coli. Staphylococcus aureus and Streptococci species

\begin{tabular}{|c|c|c|c|c|c|c|}
\hline \multirow[t]{2}{*}{ Vegetable } & \multicolumn{3}{|c|}{ Average colonies count before storage } & \multicolumn{3}{|c|}{ Average colonies count after storage } \\
\hline & $\begin{array}{l}\text { Escherichi } \\
\text { a coli }\end{array}$ & $\begin{array}{l}\text { Staphylococcu } \\
\text { s aureus }\end{array}$ & $\begin{array}{l}\text { Strepto } \\
\text { cocci } \\
\text { species }\end{array}$ & $\begin{array}{l}\text { Esche } \\
\text { richia } \\
\text { coli }\end{array}$ & $\begin{array}{l}\text { Staphylococcus } \\
\text { aureus }\end{array}$ & $\begin{array}{l}\text { Streptococci } \\
\text { species }\end{array}$ \\
\hline Amaranthus dubius & 143 & 53 & 44 & 52 & 66 & 153 \\
\hline Corchorus olitorius & 96 & 52 & 39 & 142 & 60 & 149 \\
\hline Hibiscus sabdariffa & 139 & 46 & 142 & 138 & 32 & 156 \\
\hline
\end{tabular}

Table 3 presents the test of bacteria for the sampled vegetables. The findings show that there was no statistically significant difference between before storage and after storage of the leafy vegetables.

Table.3: Pairwise test of bacteria for treatment varieties

\begin{tabular}{llll}
\hline \multicolumn{1}{c}{ Vegetable } & Before storage & After five days of storage & Coefficient of variation \\
\hline Amaranthus dubius & $5.1 \times 10^{4}(\mathrm{ab})$ & $5.5 \times 10^{4}(\mathrm{ab})$ & 14.25 \\
Corchorus olitorius & $5.4 \times 10^{4}(\mathrm{ab})$ & $6.7 \times 10^{4}(\mathrm{a})$ & \\
Hibiscus sabdariffa & $4.4 \times 10^{4}(\mathrm{~b})$ & $4.8 \times 10^{4}(\mathrm{ab})$ & \\
\hline
\end{tabular}

Table 4 shows the comparison test of Escherichia coli for the sampled vegetables. The findings indicate that there is no statistically significant difference between before storage and after storage for Corchorus olitorius and
Hibiscus sabdariffa. However, there was a statistically significant difference between before storage and after storage for Hibiscus sabdariffa.

Table.4: Pairwise test of E. coli for treatment varieties

\begin{tabular}{lccc}
\hline Vegetable & Before storage $(\mathrm{cfu} / \mathrm{g})$ & Five days in storage $(\mathrm{cfu} / \mathrm{g})$ & Coefficient of variation \\
\hline Amaranthus dubius & $143 \mathrm{a}$ & $52.0 \mathrm{c}$ & \\
$\begin{array}{l}\text { Corchorus } \\
\text { olitorius }\end{array}$ & $95.67 \mathrm{~b}$ & $142.00 \mathrm{a}$ & 6.45 \\
Hibiscus sabdariffa & $139.0 \mathrm{a}$ & $138.00 \mathrm{a}$ & \\
\hline
\end{tabular}

Table 5 presents the test of staphylococcus for treatment varieties. The results show that Amaranthus dubius and Corchorus olitorius tested for staphylococcus are not significantly different for before storage and after storage. The findings also indicate a significantly difference for Hibiscus sabdariffa before storage and after storage.

Table.5: Pairwise test of Staphylococcus for treatment varieties

\begin{tabular}{lccc}
\hline Vegetable & Before storage $(\mathrm{cfu} / \mathrm{g})$ & After storage $(\mathrm{cfu} / \mathrm{g})$ & Coefficient of variation \\
\hline Amaranthus dubius & $53.000 \mathrm{ab}$ & $66.000 \mathrm{a}$ & 14.43 \\
Corchorus olitorius & $52.000 \mathrm{ab}$ & $60.000 \mathrm{ab}$ & \\
Hibiscus sabdariffa & $46.000 \mathrm{bc}$ & $32.000 \mathrm{c}$
\end{tabular}

Table 6 shows the test of microbes of the leafy vegetables used for the study. The results show that bacteria count had increased from 49667a to 56778a after storage in the iceless cooler, Staphylococcus aureus increased from 50.333a to 52.667a and Streptococci species increased significantly from $75.00 \mathrm{~b}$ to $152.44 \mathrm{a}$. The results also show that Escherichia coli decreased from 125.89a to $110.67 \mathrm{~b}$ after five days storage. 


\begin{tabular}{llllc}
\multicolumn{5}{c}{ Table.6: Microbes test } \\
\hline Iceless cooler storage & $\begin{array}{l}\text { Bacteria } \\
(\mathrm{Cfu} / \mathrm{g})\end{array}$ & $\begin{array}{l}\text { coli } \\
(\mathrm{Cfu} / \mathrm{g})\end{array}$ & $\begin{array}{l}\text { Staphylococcus } \\
\text { aureus }(\mathrm{Cfu} / \mathrm{g})\end{array}$ & $\begin{array}{l}\text { Streptococci } \\
\text { species }(\mathrm{Cfu} / \mathrm{g})\end{array}$ \\
\hline Before storage & $49667 \mathrm{a}$ & $125.89 \mathrm{a}$ & $50.333 \mathrm{a}$ & $75.00 \mathrm{~b}$ \\
After storage & $56778 \mathrm{a}$ & $110.67 \mathrm{~b}$ & $52.667 \mathrm{a}$ & $152.44 \mathrm{a}$ \\
Coefficient of variation & 14.25 & 6.45 & 14.43 & 4.59 \\
\hline
\end{tabular}

Table 7 shows the mean comparison test of E. coli, Staphalycocus and Streptococcus for the vegetables after days of storage. The results show that there was a statistically significant difference count of $E$. coli for
Amaranthus dubius, Corchorus olitorius and Hibiscus sabdariffa. The findings did not show a significant difference for Staphylococcus and Streptococcus.

Table.7: Pairwise test of E. coli, Staphalycocus and Streptococcus for varieties after storage

\begin{tabular}{lccc}
\hline Vegetable & E. coli $(\mathrm{cfu} / \mathrm{g})$ & Staphylococcus $(\mathrm{cfu} / \mathrm{g})$ & Streptococcus $(\mathrm{cfu} / \mathrm{g})$ \\
\hline Amaranthus dubius & $97.5 \mathrm{c}$ & $59.500 \mathrm{a}$ & $98.17 \mathrm{a}$ \\
Corchorus olitorius & $118.8 \mathrm{~b}$ & $56.000 \mathrm{a}$ & $94.00 \mathrm{~b}$ \\
Hibiscus sabdariffa & $138.5 \mathrm{a}$ & $39.000 \mathrm{~b}$ & $149.00 \mathrm{a}$ \\
\hline
\end{tabular}

\subsection{Trends of deterioration of leafy vegetables}

Figures 1-3 show the rate of deterioration of leafy vegetables under ambient condition and in the iceless cooler facility. Figure 1 shows that Amaranthus dubius maintained its original weight of 2 kilograms from day zero through to the second day before losing $1.0 \%$ of its weight under the iceless cooler. By the fourth day of storage, its accumulated weight lost was $3 \%$ and by the fifth and sixth days of storage, the cumulative weight loss was $5.5 \%$ and $9.5 \%$ respectively. On the $7^{\text {th }}$ day, its cumulative loss was $15 \%$. Amaranthus dubius reduced weight by $0.5 \%$ on first day of the storage and $2 \%$ on the second day under ambient condition. There was a sharp rise in cumulative weight loss of $22 \%$ on day four and $97 \%$ loss on the seventh day (Figure 1).

Corchorus olitorius maintained its original weight of 2 kilograms from day zero to day 2 before losing $1.0 \%$ of its weight. By the fourth day of storage, there was a cumulated weight loss of $4 \%$ and on the fifth day an increase of weight loss up to $11.5 \%$ was recorded. By the sixth day, the cumulative weight loss rose to $20 \%$ (Figure 2). However, under ambient conditions, the cumulative weight loss was $4 \%$ on the third day and by the fourth day, the cumulative weight loss increased to $29 \%$ and on the sixth day it recorded an increase of $57 \%$ (Figure 2).

Hibiscus sabdariffa loss a cumulated weight of $2 \%$ on the third day under the iceless cooler facility. It also experienced a sharp increase of weight loss of $29 \%$ on the fourth day. Under ambient conditions, Hibiscus sabdariffa reduced weight by $1 \%$ a day after the storage which increased to $4 \%$ the second day. By the third and fourth days, the percentage weight loss was $29 \%$ and $57 \%$, respectively.

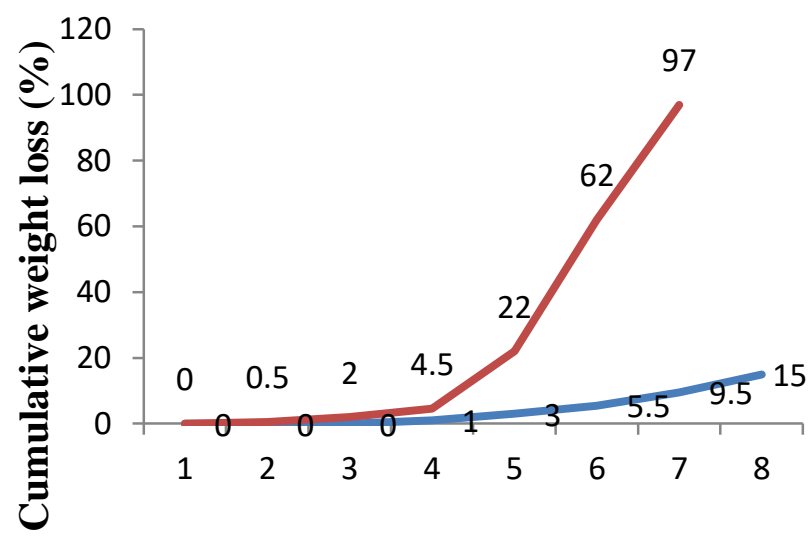

Time (Days)

Cooler

Fig.1: Cumulative weight loss of Amaranthus dubius 

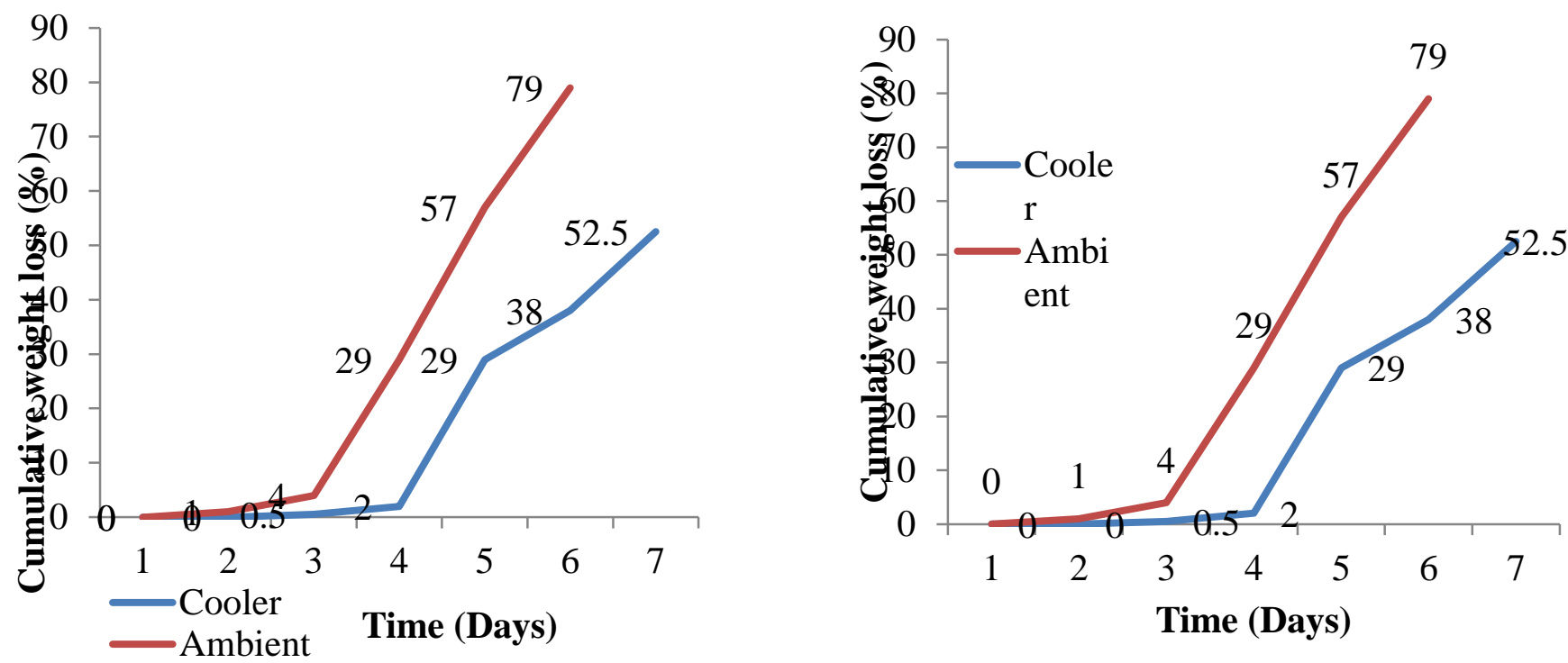

Fig.2: Cumulative weight loss of Corchorus olitorius

Fig.3: Cumulative weight loss of Hibiscus sabdariffa

Mean weight loss of leafy vegetables

Table 8 presents the results of the mean weight loss of leafy vegetables. The results of the study show that Amaranthus dubius, Corchorus olitorius and Hibiscus sabdariffa were not significantly different $(\mathrm{p}<0.01)$ between the iceless cooler facility and vegetables stored under ambient conditions. Amaranthus dubius recorded the highest weight of $1.94 \mathrm{~kg}$ at the end of the storage period under iceless cooler and Corchorus olitorius had the least weight of $1.84 \mathrm{~kg}$.

Table.8: Mean weight ( $\mathrm{kg}$ ) loss of leafy vegetables

\begin{tabular}{lccc}
\hline Storage facility & Amaranthus dubius & Corchorus olitorius & Hibiscus sabdariffa \\
\hline Iceless cooler & $1.94 \mathrm{a}$ & $1.84 \mathrm{a}$ & $1.86 \mathrm{a}$ \\
Ambient conditions & $1.42 \mathrm{a}$ & $1.04 \mathrm{~b}$ & $1.27 \mathrm{~b}$ \\
Coefficient of variation & 42.05 & 0.49 & 4.54
\end{tabular}

\subsection{Freshness rating for leafy vegetables}

Table 9 shows the freshness level of the leafy vegetables after five days of storage. The results show that Amaranthus dubius and Corchorus olitorius stored in the iceless cooler facility showed no significant differences $(p>0.01)$ in freshness rating. The results also indicate that there is no significant difference of freshness of the vegetables stored under ambient conditions.

Table.9: Freshness of leafy vegetables

\begin{tabular}{lccc}
\hline Storage type & Amaranthus dubius & Corchorus olitorius & Hibiscus sabdariffa \\
\hline Iceless cooler & $2.00 \mathrm{a}$ & $2.83 \mathrm{a}$ & $2.50 \mathrm{~b}$ \\
Ambient condition & $3.14 \mathrm{a}$ & $3.00 \mathrm{a}$ & $3.14 \mathrm{a}$ \\
Coefficient of variation & 27.52 & 24.38 & 2.51 \\
\hline
\end{tabular}




\subsection{Colour rating}

Table 10 shows the colour rating of leafy vegetables under different storage situation. The results show that Amaranthus dubius and Hibiscus sabdariffa stored under the iceless cooler facility was not different for colour (p $>0.01)$. Corchorus olitorius showed a significant difference in colour rating under the iceless cooler $(\mathrm{p}<0.01)$.

Table.10: Colour rating for the respective leafy vegetables

\begin{tabular}{lccc}
\hline Storage type & Amaranthus dubius & Corchorus olitorius & Hibiscus sabdariffa \\
\hline Iceless cooler & $1.86 \mathrm{a}$ & $2.29 \mathrm{~b}$ & $2.00 \mathrm{a}$ \\
Ambient condition & $3.14 \mathrm{a}$ & $3.29 \mathrm{a}$ & $3.29 \mathrm{a}$ \\
Coefficient of variation & 28.43 & 2.53 & 26.74 \\
\hline
\end{tabular}

\section{DISCUSSION}

The use of iceless cooling facility has a positive impact on the quality of leafy vegetables, even though there were increases of Escherichia coli count at all cases. There was a significant difference of total Escherichia coli count $(\mathrm{p}<0.01)$ between before storage and after storage of the leafy vegetables. This finding is similar to Abdullahi and Abdulkareem (2010) due to field contamination before vegetables are harvested. The study findings also indicate a significant difference $(\mathrm{p}<0.01)$ of deterioration of vegetables bought from the market and those cultivated for this study. Even though Hibiscus sabdariffa and Corchorus olitorius recorded higher counts, the variation in the data set for both market sourced vegetables and vegetables cultivated at home was 4.39.

The findings further indicate that Amaranthus dubius deteriorated at a lower rate compared with Corchorus olitorius and Hibiscus sabdariffa. While Amaranthus dubius stayed in the cooler for more than 6 days and had not deteriorated beyond saleable weight $(10 \%$ weight loss), Corchorus olitorius and Hibiscus sabdariffa could not stay such long. Under ambient conditions, it took only 3 days for all the vegetables to stay within saleable weight $(5 \%-10 \%)$. The factors accounting for weight loss of leafy vegetable is water loss. According to Wilson et al. (1999), water loss is due to the temperature of the product and air velocity.

The findings on leafy vegetable freshness indicate that Amaranthus dubius remained $100 \%$ fresh inside the iceless cooler facility for two days, while Hibiscus sabdariffa and Corchorus olitorius remained $100 \%$ fresh for only a day. Amaranthus dubius declined in freshness to $75 \%$ fresh for the next four days, while Hibiscus sabdariffa and Corchorus olitorius declined to $75 \%$ fresh for the next three days. This predisposed that Amaranthus dubius has a high potential of staying longer in the facility compared to the other leafy vegetables. Observation of leafy vegetables stored under ambient conditions show that they loss their freshness within the $1^{\text {st }}$ day and deteriorated to $50 \%$ in the $2^{\text {nd }}$ day of storage.

\section{CONCLUSION}

Leafy vegetables are vital sources of minerals and vitamins for human health and development, hence, the need to conserve the quality and shelf life of vegetables through the use of iceless cooler facility. The iceless cooler facility has the tendency to retain freshness and colour of vegetables for a short while compared to vegetables stored under ambient temperature. The coefficient of variations confirms the efficiency of the iceless cooler facility which should be adopted by farmers and traders for the storage of leafy vegetables in order to reduce postharvest loss. Given the efficiency of the iceless cooler facility, it is prudent to use it for preserving the quality and shelf life of Amaranthus dubius, Corchorus olitorius and Hibiscus sabdariffa.

\section{ACKNOWLEDGEMENTS}

We wish to thank the Director of Savannah Agriculture Research Institute for granting us permission to conduct the experiment in their laboratory.

\section{REFERENCES}

[1] Abdullahi, I.O. \& Abdulkareem, S. (2010). Bacteriological Quality of SomeReady to Eat Vegetables as Retailed and Consumed in SabonGari, Zaria, Nigeria. Bayero Journal of Pure and Applied Sciences, Vol. 3(1), 173-175.

[2] Adam, N. J., Al-hassan, S. \& Akolgo, D. A. (2016). Small scale irrigation and rural poverty reduction in the Upper East Region of Ghana. African Journal of Science and Research, Vol. 5 (2), 38-42.

[3] Allende, A., Aguayo, E., \& Artes, F. (2004). Microbial and sensory quality of commercial fresh processed red lettuce throughout the production chain and shelf life. International Journal of Food Microbiology, Vol. 91, 109-117.

[4] Amagloh, F. K., \& Nyarko, E. S. (2012). Mineral nutrient content of commonly consumed leafy vegetables in Northern Ghana. African Journal of Food, Agriculture, Nutrition and Development, Vol. 12(5), 6397-6408. 
[5] Babalola, O.O., Tugbobo O. S. \& Daramola, A.S. (2010). Effect of processing on the Vitamin C content of seven Nigerian green leafy vegetables. Advance Journal of Food Science and Technology, Vol. 2(6), 303-305.

[6] Babalola, S.O., Babaloal, A.O., \& Aworh, O. C. (2001). Conditional Attributes of the Calyces of Roselle (Hibiscus sabdariffa L.). The Journal of Food Technology in Africa, Vol. 6 (4), 133-134.

[7] Boyette, M. D., Ritchie, D. F., Carballo, S. J., Blankenship, S. M., \& Sanders, D. C. (1993). Chlorination and postharvest disease control. Horticultural Technology, Vol. 3, 395-400.

[8] Buyukunal S. K., Issa, G., Aksu, F. \& Vural, A. (2015). Microbiological quality of fresh vegetables and fruits collected from supermarkets in Istanbul, Turkey. Journal of Food and Nutrition Sciences, Vol. 3(4), 152-159.

[9] Delaquis, P. J., Stewart, S., Toivonen, P. M. A., \& Moyls, A. L. (1999). Effect of warm, chlorinated water on the microbial flora of shredded lettuce. Food Research International, Vol. 32, 7-14.

[10] Gogo, E. O., Opiyo, A., Ulrichs, C. \& HuyskensKeil, S. (2016). Postharvest treatments of African leafy vegetables for food security in Kenya: A review. African Journal of Horticulture Science, Vol. 9, 32-40.

[11] Jacxsens, L., Devlieghere, F., Ragaert, P., Vanneste, E., \& Debevere, J. (2003). Relation between microbiological quality, metabolite production and sensory quality of equilibrium modified atmosphere packaged fresh-cut produce. International Journal of Food Science and Technology, Vol. 31, 359-366.

[12] Jonadet, M., Bastide, J., Bastide, P., Boyer, B., Carnat, A.P. and Lamaison, J.L. (1990).In Vitro Enzyme Inhibitory and in Vivo Cardio- Protective Activities of Hibiscus sabdariffa. Pharmacol Belgium, Vol. 45(2), 120 - 124.

[13] Nguyen, C. \& Cardin, F. (1994). The microbiology of minimally processed fresh fruits and vegetables. Critical Reviews in Food Science and Nutrition, Vol. 34, 371-401.

[14] Nicol, K., Darko, J.O., and Ofosu, A., (1997). A manual of post-harvest technology of major food crops in Ghana. Postharvest Development Unit Accra, Ghana.

[15] O’Connor-Shaw, R. E., Roberts, R., Ford, A. L., \& Nottingham, S. M. (1994). Shelf life of minimally processed honeydew melon, kiwifruit, papaya, pineapple and cantaloupe. Journal of Food Science, Vol. 59, 1202-1206.

[16] O’Connor-Shaw, R. E., Roberts, R., Ford, A. L., \& Nottingham, S. M. (1996). Changes in sensory quality of sterile cantaloupe dices stored in controlled atmospheres. Journal of Food Science, Vol. 61, 847-851.

[17] Sapers, G. M., Miller, R. L., Jantschke, M., \& Mattrazzo, A. M. (2001). Factors limiting the efficacy of hydrogen peroxide washes for decontamination of apples containing Escherichia coli. Journal of Food Science, Vol. 65, 529-532.

[18] Schippers, R.R. (2002). African indigenous vegetables. An overview of the cultivated species. University of Greenwich, Natural Resources Institute, London, UK.

[19] Smith, F. I. \& Eyzaguirre, P. (2007). African leafy vegetables: Their role in the World Health Organization's Global Fruit and Vegetables Initiative. African Journal of Food Agriculture, Nutrition and Development, Vol. 7(3), 1-17.

[20] Tweneboah, C.K. (2000). Vegetables and Spices in West Africa with Special Reference to Ghana. Tweneboah, C.K. and CO-WOOD Publishers: Koduah-Ville, North Dzowulu, Accra.

[21] Warren, K. (2005). Category offers promise for processors, retails. Fresh cut magazine, June, http://www.freshcut.com/pages/arts.

[22] Wilson, L. G., Boyette, M. D., \& Estes, E.A (1999). Postharvest Handling and Cooling of Fresh Fruits, Vegetables, and Flowers for Small Farms. Leaflet 800-804. North Carolina Cooperative Extension Service. 17 p. Accessed online at http://www.foodsafety.org/nc/nc1055.htm. 